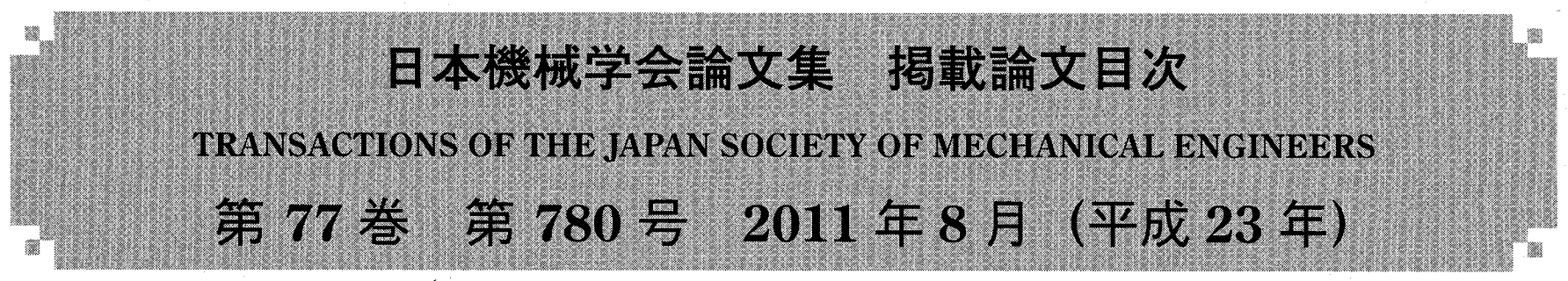

\title{
A 編目次
}

材料力学, 機械材料など

http:/www.jstage.jst.go.jp/browse/kikaia/-char/ja

\section{研究 展 望}

高温プラント機器の構造健全性評価に関する最近の動向・

\section{一 般 論 文}

粘塑性・クリープ分離型構成モデルの鉛フリーはんだへの適用 内圧を受けるガスケット付き箱型フランジ締結体の有限要素応力解析と密封性能評価

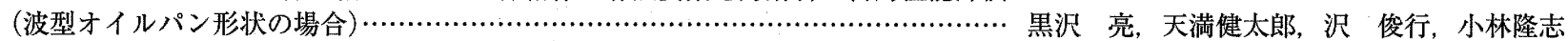
サスペンション部品の非線形座屈現象に関する形状最適化の検討 …………………... 新谷浩平, 長谷高明, 伊藤 聡, 畔上秀幸 双結晶モデルによる局所変形開始およびき裂発生におよほすす結晶方位依存性評価 ‥ 土屋佑太，三浦節男，柴野純一，尾崎義治，小林道明 直交異方性超弾性モデルの提案と発電装置用繊維強化ゴムシール材料への適用…………………中和之, 松田昭博, 渡部 修 展伸マグネシウム合金の低サイタル疲労変形挙動と疲労寿命評価…………塩澤和章, 北島 純, 上梨智弘, 村井 勉, 高橋 泰 CFRP 直交積層板の熱残留応力緩和に伴う経時寸法変化の予測

表面波によるコンロッドのき裂進展評価 荒尾与史彦，奥土居由貴江，武田真一，小柳 潤，宇都宮真，川田宏之 三次元異材接合体界面角部の特異応力場の評価

(応力 $\sigma_{\theta \theta}$ に関する最大強度の評価) 新井國夫，江川宣也，水口義久

損傷力学に基づくねずみ鋳鉄材の材料モデリングと疲労寿命予測への適用........... 古口日出男, 齊藤裕一 …… 岡 正徳, 都井 裕 原子空孔を含むグラフェンとグラファイトの引張りに関する分子動力学シミュレーション…………………伊藤明彦, 岡本伸吾 ハニカムコアサンドイッチパネルの静的局部圧縮特性・ 再結晶現象に対する結晶格子スケールの離散的保存則の定式化 小林志好, 大塚年久, 石川篤志, 岸本喜直 ミクロ情報を基礎とする Multi-phase-field 法を用いた Ni-Ti 形状記憶合金の相変態に関する研究………………松木孝信, 齋藤賢一 アルミニウム合金および炭素鋼の耐食性に及ぼすチタン微粒子衝突処理の効果……森田辰郎, 従野友裕, 加賀谷忠治, 宮坂四志男 酸性ガス雾囲気で長期間使用された GFRP 製大型スクラバーの損傷状態 ……………森田辰郎, 馬㴊信太, 藤井善通, 平野未來 各種プラスチック材料の広ひずみ速度域での動的引張強度特性 谷村眞治, 林 寛幸, 山本照美 高温・酸化/還元環境下における機械的特性評価法の開発

…………… 渡辺 智, 佐藤一永, 武山陽平, 井口史匡, 八代圭司, 雨濹浩史, 湯上浩雄, 橋田俊之, 水崎純一郎, 川田達也 微粒子ピーニングを施した純鉄のプラズマ窒化挙動.... 菊池将一, 福岡隆弘, 小茂鳥潤 ナノ銅粉末を用いた NIL 犠牲樹脂型インサート MIM によるマイクロ構造体の作製 ‥ 西笅和明, 田邊大貴, 鹿子泰宏, 田中茂雄

\section{再 録 論 文}

焼焚めで構成されたセラミックス製スリーブの焼外し条件の検討· 栗 文椮, 野田尚昭, 酒井悠正, 高瀬 康

$$
\text { ノ - ト }
$$

\section{$\mathbf{B}$ 編日次 流体工学, 流体機械, 熱工学, 内燃機関, 動力・エネルギーシステムなど http://www.jstage.jst.go.jp/browse/kikaib/-char/ja}

(流体工学, 流体機械)

\section{一 般 論 文}

非ニュートン流体の押出し金型内流れの一次元・二次元混合モデル 衣川洋史，津田武明，中野公一，京藤敏達 
小型軸流ファンにおける前進翼と箱形ケーシングの干渉が翼通過周波数騒音に与える影響

岩瀬 拓, 日沖哲也, 加藤義彦, 旦野太郎, 関口 治, 古川雅人

ロケットエンジン用ターボポンプの入口配管の音響効果を考虑したキャビテーションサージの一次元解析

(第 3 報, 非線形要素による周波数の不連続変化) 南里秀明, 藤原徹也, 河南広紀, 吉田義樹

1620

\section{技 術論 文}

同一空間を分煙化するための換気システムの開発・ 岩永正裕, 杉山 明, 金子裕一郎, 伊藤友和 1641

(熱工学, 内燃機関，動カ・エネルギーシステムなど)

一 般 論 文

高温場滞在時間がフラーレン・PAH の燃焼生成に及ほすす影響

雑賀達也, 崎田容平, 芝原正彦

次世代電池を備えた軽量電動アシストトライサイクルの環境評価と導入効果.......

无充

1652

技術進歩を内生化したエネルギー経済モデルの開発と $\mathrm{CO}_{2}$ 回収貯留技術の導入可能性評価

楠 朋也, 古林敬顥, 中田俊彦

〔機械力学，計測，自動制御〕

\section{一 般 論 文}

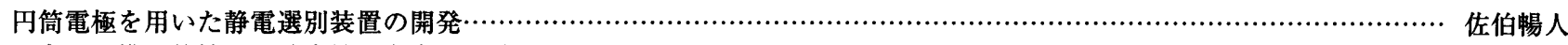

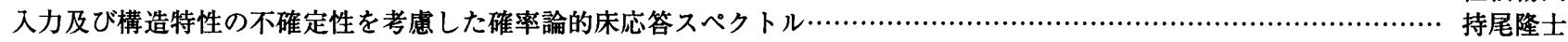

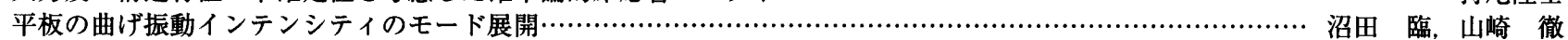
衝撃力を利用した環境振動・地震用 TMD に関する研究…………皆川佳祐, 藤田 聡, 小見俊夫, 新野桂也, 山方啓司, 宮野 宏 超音波パルスの瞬時振動数を用いた新たな診断法

(エポキシ樹脂系接着剂の接合度評価) 井上卓見，中野貴裕

超音波モー夕の高速位置決め手法・ 涌井伸二，佐久間圭輔

第 1 次自己回㷌モデルによるゆらぎの解析. 藤田貴行，塚本 哲，多田 茂

非接触型変位計を用いた小口径配管の振動応力評価法

前川 晃, 野田満靖

スイッチのサイズ及び形状が抵抗膜方式タッチパネル携帯端末の操作性に及ほす影響について……西村崇宏, 瀬尾明彦, 土井幸輝 緊張性アテトーぜ型脳性麻㾇の一患者を対象とした描画支援システムの開発

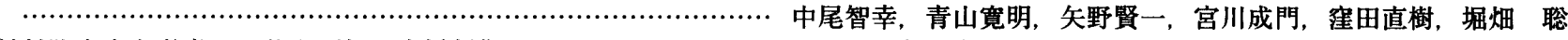
材料除去率を考虑した仕上げ加工支援制御…………………………矢野賢一, 酒井伸明, 前刀大輝, 佐々木利春, 安藤幸二

2953 2962 2971 2982 2993 3007 3017 3025 3036 3047 3058

\section{技 術 論 文}

層間を部分的に非接着にした CFRP 積層はりの減衰振動測定と FEM 解析…..........

鈴木浩治 輪軸の質量アンバランスに起因する鉄道車両の車体振動抑制・ 富岡隆弘, 瀧上唯夫, 山之口学, 東 義之, 鈴木和馬 排気温度波形を用いた内燃機関失火検出法に関する研究 田村雅之

3069 3078 3094

筋負担の総合評価に基づく人間工学的設計法に関する検討

（第 2 報，妥協解群の提示による設計者の意思決定支援） 茅原崇德, 和泉太樹, 瀬尾明彦 品質工学の逆解法を用いた制御因子の影響の評価

(制御因子中の有機物の影響)

入れ子を有する複雑形状の巧妙加工.

四角すい台の仕上げ加工に基づく 5 軸マシニングセンタの工作精度試験方法の開発

同時 5 軸制御による円すい台仕上げ加工試験用 NC データの解析

堤 正臣, 佐伯智之, 木落清志郎, 崔 成日, 井原之敏 田辺郁男, 井山徹郎, ブレー ホアン

\section{技術論 文}




\section{(訂正)}

訂正 : CTAB/NaSal 水溶液の平行平板間せん断流れにおけるクリープ試験・流動複屈折測定および可視化実験

[日本機械学会論文集 B 編, Vol. 77 (2011), No. 775, pp. 842-852] …………….. 山下敦史, 森 網規, 沢 和洋, 山本㴊宏

訂正：管状火炎を用いた過熱蒸気発生器の開発

[日本機械学会論文集 B 編, Vol. 77 (2011), No. 776, pp. 997-1001]

小林侑弘, 松本亮介, 小澤 守, 毛笠明志, 竹森利和, 久角喜德, 香月正司, 船越 弘

\section{論文募集}

\section{日本機械学会論文集 \\ [D\&D2011]特集 2012 年 5 月号 $\mathrm{C}$ 編}

本会では，1935 年 2 月に論文集を発行して以来，常に高レ ベルの研究成果を斯界の方々に提供しております。このたび本 会論文集では, 類似/共通/関連テーマの論文を一括編集した 標記テーマの特集号の発行を予定しております，会員各位の積 極的なご応募をお願いいたします。

\section{1. 論文募集要領}

\section{テーマ/掲載誌「D\&D2011」(論文集 C 編)}

機械力学・計測制御部門が毎年開催する Dynamics and Design Conferenceは, 日本機械学会における最大級の部門講演会で す．D\&D2011 は，24のオーガナイズトセッションを中心に， 「部門創設 25 周年、新たなる躍動」のテーマのもと, 2011 年 9 月 5 日 (月) 〜9 日 (金) に高知工科大学で開かれます。 この講演会から, 機械力学と計測制御に関する研究の最新動 向を, 特集号の形で紹介します，投稿は, D\&D2011 の講演
とディスカッションを経たものに限定されます．従来の個別 テーマとは異なる「わが国における機械力学と計測制御の最 新の研究技術動向」に関する本特集号にご期待ください. 投稿の締切 2011 年 10 月 21 日 (金) 揭載号 2012 年 5 月号

2. 論文の執筆と取扱い

（1）論文の執筆については「執筆要綱－論文の書き方および 投稿の手引一」に拠ります。本会のホームページをご参照 下さい.

(http://www.jsme.or.jp/publish/ronbun/JSME_ Manual_20100730.pdf)

（2）校閲の関倸で，応募論文でも予定号以降に揭載すること もあります。

（3）日本機械学会投稿校閲審查システム（http:/Trans-JSME. edmgr.com/) を利用してご投稿下さい，その際，セクショ ンノカテゴリーは, 『C1 特：D\&D2011』を選定し, 手続 きをして下さい.

3. 問い合わせ先

日本穖械学会 論文編修委員会／電話（03）5360-3502/ FAX (03) 5360-3508/E-mail : transact@jsme.or.jp

本会部門の編集による英文ジャーナル（電子版）を公開しておりますのでご覧下さい。この英文ジャーナルはホームページ上に随時 揭載し，閲覽無料で公開しております。

- Journal of Fluid Science and Technology（JFST）〔2006 年 6 月創刊〕

(http://www.jstage.jst.go.jp/browse/jfst)

Journal of Thermal Science and Technology（JTST）【2006 年 6 月創刊]

(http://www.jstage.jst.go.jp/browse/jtst)

Journal of Environment and Engineering (JEE) 〔2006 年 8 月創刊〕

(http://www.jstage.jst.go.jp/browse/jee)

Journal of Biomechanical Science and Engineering（JBSE）【2006 年 10 月創刊] (http://www.jstage.jst.go.jp/browse/jbse)

Journal of Solid Mechanics and Materials Engineering（JSMME）〔2007 年 1 月創刊〕 (http://www.jstage.jst.go.jp/browse/jmmp)

Journal of Advanced Mechanical Design, Systems, and Manufacturing（JAMDSM）（2007 年 1 月創刊] (http://www.jstage.jst.go.jp/browse/jamdsm)

Journal of System Design and Dynamics (JSDD) 〔2007 年 3 月創刊〕 (http://www.jstage.jst.go.jp/browse/jsdd)

Journal of Power and Energy Systems (JPES) 〔2007 年 3 月創刊〕 (http://www.jstage.jst.go.jp/browse/jpes)

Journal of Computational Science and Technology（JCST）〔2007 年 11 月創刊〕

(http://www.jstage.jst.go.jp/browse/jcst)

Journal of Space Engineering（JSE）〔2008 年 1 月創刊〕

(http://www.jstage.jst.go.jp/browse/spacee)

Journal of Mechanical Systems for Transportation and Logistics（JMTL）【2008 年 1 月創刊] (http://www.jstage.jst.go.jp/browse/jmtl) 